\title{
Effects of Laser Probes and Computed Tomography Findings on Ureterorenoscopic Laser Lithotripsy Success Rate, Laser Time, Laser Energy Level and Operative Time for Distal Ureteral Stones
}

\author{
Distal Üreter Taşlarında Lazer Probunun ve Bilgisayarlı Tomografi Bulgularının \\ Üreterorenoskopik Lazer Litotripsi Başarısı, Lazer Süresi, Lazer Enerji Düzeyi ve Operasyon \\ Süresi Üzerine Etkileri
}

\author{
(D) Serdar Çelik1,2, (D) Ozan Bozkurt33, (D) Işıl Başara4, (D) Özgür Gürboğa33, (D) Ömer Demir33, (D) Mustafa Seçil4, (D) Adil Esen³ \\ 1 İzmir Bozyaka Training and Research Hospital, Clinic of Urology, İmir, Turkiye \\ 2Dokuz Eylül University Faculty of Medicine, Institute of Oncology, Depratment of Basic Oncology, Izmir, Turkiye \\ ${ }^{3}$ Dokuz Eylül University Faculty of Medicine, Department of Urology, Izmir, Turkiye \\ ${ }^{4}$ Dokuz Eylül University, Faculty of Medicine, Department of Radiology, Izmir, Turkiye
}

\section{What's known on the subject? and What does the study add?}

Stone diameter, volume and Hounsfield units values were significant predictors of laser energy level, ureterorenoscopy and laser time for distal ureteral stones. Also, use of a thinner probe decreased total laser time, laser energy level and laser energy/time ratio.

\begin{abstract}
Objective: To investigate the effect of preoperative non-contrast computed tomography (NCCT) findings and peroperative laser probe selection on total laser time, energy level and ureterorenoscopy (URS) time for distal ureteral stones.

Materials and Methods: We prospectively evaluated 72 patients with single distal ureteral stone measuring 5-25 mm in diameter on NCCT, who were treated with ureteroscopic lithotripsy (URSL) between June 2015 and October 2016. The patients were divided into two groups according to probe selection as $365 \mu \mathrm{m}$ and $550 \mu \mathrm{m}$ groups. Stone diameters, stone volume and Hounsfield units (HU) measured on NCCT, and URSL findings were noted at the end of the treatment. These findings were compared between the groups. Also the possible predictive value of NCCT findings was evaluated for URSL data.

Results: There were 17 patients in the $365 \mu \mathrm{m}$ and 55 patients in the $550 \mu \mathrm{m}$ groups. There was no significant difference in URSL success rate and other predictive data between the groups. However, among the peroperative data, laser time, laser energy level and laser energy/time ratio were significantly lower in the $365 \mu \mathrm{m}$ group compared to the $550 \mu \mathrm{m}$ group $(\mathrm{p}<0.05)$. Correlation analysis indicated that total laser time and URS time were correlated with stone diameter, stone volume, HU values and density (HD). Laser energy level was only correlated with longitudinal stone diameter and HD.

Conclusion: Stone diameter, volume and HU values are significant predictors of laser energy level, URS and laser time for distal ureteral stones. Also, use of a thinner probe decreases total laser time, laser energy level and laser energy/time ratio. In addition, thinner laser probe shortens URS time. Keywords: Distal ureteral stone, Hounsfield units (HU), Laser lithotripsy, Non-contrast computed tomography (NCCT), Ureterorenoscopy (URS)
\end{abstract}

Öz

Amaç: Distal üreter taşlarında, preoperatif kontrastsız bilgisayarlı tomografi (BT) bulgularının ve peroperatif lazer prob seçiminin toplam lazer süresi, enerji düzeyi ve üreterorenoskopi (URS) zamanı üzerine etkisini araştırmayı amaçladık.

Correspondence: Serdar Çelik MD, İzmir Bozyaka Training and Research Hospital, Clinic of Urology, İzmir, Turkiye Phone: +90 2324123451 E-mail: serdarcelik84@hotmail.com ORCID-ID: orcid.org/0000-0003-0939-9989 Received: 06.11.2018 Accepted: 18.12.2018

Cite this article as: Çelik S, Bozkurt O, Başara I, Gürboğa Ö, Demir Ö, Seçil M, Esen A. Effects of Laser Probes and Computed Tomography Findings on Ureterorenoscopic Laser Lithotripsy Success Rate, Laser Time, Laser Energy Level and Operative Time for Distal Ureteral Stones. J Urol Surg 2019;6(3):201-206.

oCopyright 2019 by the Association of Urological Surgery / Journal of Urological Surgery published by Galenos Publishing House. 
Gereç ve Yöntem: Haziran 2015 - Ekim 2016 tarihleri arasında, URS ile tedavi edilen ve BT'de 5-25 mm çaplı, tek, distal üreter taşı olan 72 hasta prospektif olarak değerlendirildi. BT'de ölçülen taş çapı, taş hacmi ve hounsfield ünitesi (HU) ile URS bulguları not edildi. Prob seçimine göre 365 $\mu \mathrm{m}$ ve $550 \mu \mathrm{m}$ olarak iki gruba ayrılan hastalarda tüm veriler lazer prob grupları arasında karşılaştırılarak değerlendirildi. Ayrıca URS verilerini etkileyebilecek olası BT bulgularının tahmini prediktif etkileri incelendi.

Bulgular: Toplam 72 hastadan, $365 \mu \mathrm{m}$ prob grubunda 17 hasta ve $550 \mu \mathrm{m}$ prob grubunda 55 hasta mevcuttu. URS başarı oranı ve diğer prediktif veriler gruplar arasında anlamlı değildi. Ancak, peroperatif verilerden lazer süresi, lazer enerji düzeyi ve lazer enerji/süre oranı 365 m prob grubunda $550 \mu \mathrm{m}$ prob grubuna göre anlamlı daha düşüktü $(p<0,05)$. Korelasyon analizinde toplam lazer süresi ve URS süresinin taş çapı, taş hacmi, HU değeri ve HU dansitesi (HD) ile korele olduğu gözlendi. Lazer enerji düzeyi ise sadece longitudinal taş çapı ve HD ile koreleydi.

Sonuç: Distal üreter taşlarında taş çapı, hacmi ve HU değerleri lazer enerji düzeyi, URS ve lazer süresini öngören faktörlerdir. Ayrıca, daha ince lazer prob kullanımı toplam lazer süresini, lazer enerji düzeyini ve lazer enerji/süre oranını azaltmaktadır. Ayrıca, ince lazer probu URS süresini kısaltmaktadır.

Anahtar Kelimeler: Distal üreter taşı, Hounsfield units (HU), Lazer litotripsi, Kontrastsız bilgisayarlı tomografi (BT), Üreterorenoskopi (URS)

\section{Introduction}

Ureteroscopy (URS) procedure is an appropriate treatment modality for ureteral stones (1). The holmium:yttriumaluminum-garnet (Ho:YAG) laser has been considered the standard lithotripsy modality for ureteroscopic lithotripsy (URSL) for the past 2 decades $(2,3)$. With the development of semirigid and flexible URS technology and introduction of better instrumentation, including the Ho:YAG laser, URSL has improved in efficacy while sustaining a low morbidity and high success profile $(4,5)$. In current studies, URSL stone-free (SF) rates were reported as $94.2 \%, 89.4 \%$, and $84.5 \%$, for distal, mid, and proximal ureteral stones, respectively (6).

Non-contrast computed tomography (NCCT) is the gold standard imaging modality to evaluate patients with urinary stones, providing predictive information for treatment planning $(7,8)$. NCCT provides stone measurements (size and volume), stone location and stone density [Hounsfield units (HU) measurements]. Absolute HU inversely correlates with the effectiveness of extracorporeal shock wave lithotripsy (SWL) and has also been proposed to affect SF rates after URSL and percutaneous nephrolithotomy (PNL) (9-12). Stone fragmentation is an important factor for SF status, laser and operative times. Therefore, it is important to define the predictive factors affecting stone fragmentation and these factors may also be useful in predicting SF status, laser and operative times for URSL. In a recent study, URSL procedures were retrospectively analyzed and predictive factors for operative time and success were investigated and identified (13).

The purpose of our investigation was to prospectively evaluate the effect of preoperative NCCT findings and peroperative laser probe selection on treatment success rate, cumulative Ho:YAG laser time, URS time and laser energy level for single distal ureteral stones.

\section{Materials and Methods}

After approval was obtained from the Local Ethics Committee, we prospectively evaluated patients $>18$ years old who underwent URSL for single distal ureteral stone $5-25 \mathrm{~mm}$ in diameter from March 2015 to October 2016. The patients were evaluated with NCCT before URSL. The exclusion criteria were stones of $<5$ or $>25 \mathrm{~mm}$ in diameter, obstructive and multiple stones, stones requiring emergency drainage (fever, Systemic Inflammatory Response syndrome, sepsis, urinary tract infection), patients with solitary kidney and patients with congenital urinary tract anomalies. Mid-proximal ureteral stones were also excluded. NCCT images using $2 \mathrm{~mm}$ sections with the liver's dome as cranial border and the pubis joint as caudal border at $100 \mathrm{~mA}$ 120 kV (Brilliance 64, Philips ${ }^{\circledR}$, Best, The Netherlands) were taken. All NCCT findings were evaluated by a radiologist. Stone diameters (longitudinal and transverse) were calculated in 2 different planes and the maximum diameters of the stones were taken into consideration. Stone volumes were measured using a computer programme. HU values were measured as previously described by Celik et al. (12) for the largest diameter of the stone (longitudinal or transverse) with bone window and large magnification. After serial measurements of the highest $\mathrm{HU}$ value (HUmax) and the lowest HU value (HUmin), $\mathrm{HU}$ value was calculated as the average of these two values (HUave). The difference in HU (HUdiff) was calculated as the difference between the HUmax and the HUmin values, as previously defined by Celik et al. $(14,15)$ Hounsfield density (HD) was calculated as HUmax divided by stone size (16). All URSL treatments were performed with a 8/9.8 F rigid ureteroscope (Karl Storz ${ }^{\circledR}$, Tuttlingen, Germany), $365 \mu \mathrm{m}$ PercuFib or $550 \mu \mathrm{m}$ Rigifib laser probes (LISA ${ }^{\circledR}$ laser products $\mathrm{OHG}$, KatlenburgLindau, Germany) and a 80 watt Ho:YAG laser device (Sphin $x^{\circledR}$ Livermore, CA, USA). Laser probe was randomly selected during the the operation. Stone fragmentation was monitored using the Storz endovision system (Karl Storz ${ }^{\circledR}$, Tuttlingen, 
Germany) throughout the procedure. All laser procedures were performed with 1.5 joules energy, 12 watts power and 8 hertz frequency. Usage of forceps and/or basket catheter and the data on obstruction (no obstruction/partial obstruction/ complete obstruction) and impaction (no impaction/partial impaction/complete impaction) were noted according to URS observation during the procedure. The total laser energy level, laser time, URS time and operative time were noted at the end of the operation. Necessity of J stent placement was decided according to the operation findings. Status of stone impaction and obstruction and J stent placement were also noted. URSL success was defined as SF (absence of all of clinical significant and insignificant stones) status at the end of the operation.

\section{Statistical Analysis}

Success status was evaluated as SF and residual fragments (RF). Type of laser probe used was also evaluated and divided into two groups as 365 and $550 \mu \mathrm{m}$ laser probe groups. Data were analyzed using the Statistical Package for Social Sciences, version 20.0 (SPSS, Chicago, III) software program. Nonparametric correlations between possible predictive parameters for URSL success were compared by using Pearson's correlation coefficient. The Mann-Whitney $\mathrm{U}$ test and Pearson chi-square test were used to compare demographic and radiologic parameters between 365 and $550 \mu \mathrm{m}$ groups. Data are given as mean \pm standard deviation. However, the results of analysis are given as median data. Statistical significance was defined as $p<0.05$.

\section{Results}

A total of 72 patients with distal ureteral stones were included. Patient and stone characteristics are given in Table 1. Correlation between predictive radiologic parameters measured on NCCT images and peroperative URSL data was investigated in all the 72 patients. Correlation results are given in Table 2. In correlation analysis of 72 patients, laser time was strongly correlated with longitudinal and transverse diameters of stone, stone volume, HUmax, HUmin and HUave and negatively correlated with HD. URS time was found to positively correlate with longitudinal and transverse stone diameters and negatively correlate with HD. Laser energy was also positively correlated with only longitudinal stone diameter and negatively correlated with HD. However, energy/time ratio was not found to correlate with any predictive data. Stone diameters, volume and HU measurements were not significantly different between the groups with presence of obstruction and impaction. There were 17 patients in the $365 \mu \mathrm{m}$ group and 55 patients in the $550 \mu \mathrm{m}$ probe group. Patients and stone characteristics of the groups and comparison of statistical analysis results are given in Table 3. The rate of patients treated with SWL before the URSL procedure was found to be significantly higher in the 365 $\mu \mathrm{m}$ group compared to $550 \mu \mathrm{m}$ group $(\mathrm{p}<0.05)$. There was no significant difference in URSL success rate and other predictive data between the groups. However, in the peroperative data, laser time, laser energy level and laser energy/time ratio were significantly lower in the $365 \mu \mathrm{m}$ group compared to the 550 $\mu \mathrm{m}$ group $(\mathrm{p}<0.05)$. After exclusion of patients with previous SWL, 61 patients were evaluated (11 patients in the $365 \mu \mathrm{m}$ group and 50 patients in the $550 \mu \mathrm{m}$ group) and almost all parameters were similar between the groups. However, URS time was found to be shorter in the $365 \mu \mathrm{m}$ group than in the $550 \mu \mathrm{m}$ group ( $17.5 \mathrm{~min}$ vs $24.4 \mathrm{~min}, \mathrm{p}=0.036$ ).

Table 1. Patient and stone characteristics

\begin{tabular}{|c|c|c|}
\hline & & $\begin{array}{l}\text { All patients }(n=72) \text { mean } \pm \\
\text { SD (minimum-maximum) }\end{array}$ \\
\hline \multicolumn{2}{|l|}{ Mean age (year) } & $46.9 \pm 13.2(18.6-71.7)$ \\
\hline \multicolumn{2}{|l|}{ BMI (kg/m²) } & $25.8 \pm 3.1(15.7-32)$ \\
\hline \multicolumn{2}{|c|}{$\begin{array}{l}\text { Longitudinal diameter of stone } \\
(\mathrm{mm})\end{array}$} & $10.6 \pm 3.7(5-21)$ \\
\hline \multicolumn{2}{|c|}{ Transvers diameter of stone (mm) } & $8.3 \pm 3.1(3.5-25)$ \\
\hline \multicolumn{2}{|l|}{ Stone volume $\left(\mathrm{mm}^{3}\right)$} & $416.1 \pm 578.3(41.6-3900)$ \\
\hline \multicolumn{2}{|l|}{ HUmax (HU) } & $1116.8 \pm 281.3(270-1596)$ \\
\hline \multicolumn{2}{|l|}{ HUmin (HU) } & $780.5 \pm 257.5(204-1435)$ \\
\hline \multicolumn{2}{|l|}{ HUave (HU) } & $948.6 \pm 252.3(252-1515.5)$ \\
\hline \multicolumn{2}{|l|}{ HUdiff (HU) } & $336.3 \pm 190.3(36-824)$ \\
\hline \multicolumn{2}{|l|}{$\mathrm{HD}(\mathrm{HU} / \mathrm{mm})$} & $111.8 \pm 38.9(24.8-213.9)$ \\
\hline \multicolumn{2}{|l|}{ Laser time (min) } & $9.5 \pm 6.1(1-25)$ \\
\hline \multicolumn{2}{|l|}{ Laser energy (joule) } & $2409.9 \pm 2928.3$ (17-18900) \\
\hline \multicolumn{2}{|c|}{ Laser energy/time ratio (J/min) } & $218.5 \pm 179.5(2.8-821.7)$ \\
\hline \multicolumn{2}{|l|}{ URS time (min) } & $23.6 \pm 10.6(3-50)$ \\
\hline \multirow[t]{2}{*}{ Laser probe, n (\%) } & $365 \mu \mathrm{m}$ & $17(23.6 \%)$ \\
\hline & $550 \mu \mathrm{m}$ & $55(76.4 \%)$ \\
\hline \multirow[t]{2}{*}{ J stent status, n (\%) } & Yes & $49(68.1 \%)$ \\
\hline & No & $23(31.9 \%)$ \\
\hline \multirow{2}{*}{$\begin{array}{l}\text { Previous SWL status, } \\
\mathrm{n}(\%)\end{array}$} & Yes & $11(15.3 \%)$ \\
\hline & No & $61(84.7 \%)$ \\
\hline \multirow{3}{*}{$\begin{array}{l}\text { Obstruction } \\
\text { presence, n (\%) }\end{array}$} & No & $37(51.4 \%)$ \\
\hline & Partial & $24(33.3 \%)$ \\
\hline & Complete & $11(15.3 \%)$ \\
\hline \multirow{3}{*}{$\begin{array}{l}\text { Impacte stone } \\
\text { presence, n (\%) }\end{array}$} & No & $40(55.6 \%)$ \\
\hline & Partial & $21(29.2 \%)$ \\
\hline & Complete & $11(15.3 \%)$ \\
\hline
\end{tabular}

SD: Standard deviation, BMI: Body mass index, HU: Hounsfield units, HUmax: Highest hounsfield units value, HUmin: Howest hounsfield units value, HUave: The average of hounsfield units values, HUdiff: The difference of hounsfield units values, HD: Hounsfield density, SWL: Extracorporeal shock wave lithotripsy, URS: Ureterorenoscopy 
Table 2. Correlation between preoperative predictive radiologic findings and ureteroscopic lithotripsy findings

\begin{tabular}{|c|c|c|c|c|}
\hline & Laser time & Laser energy & $\begin{array}{l}\text { Laser energy/time } \\
\text { ratio }\end{array}$ & URS time \\
\hline \multirow[t]{2}{*}{ Age } & $R=0.199$ & $R=0.106$ & $\mathrm{R}=0.031$ & $\mathrm{R}=0.169$ \\
\hline & $p=0.093$ & $p=0.376$ & $p=0.796$ & $p=0.156$ \\
\hline \multirow[t]{2}{*}{ BMI } & $R=0.106$ & $R=0.025$ & $R=0.029$ & $R=0.083$ \\
\hline & $p=0.376$ & $p=0.833$ & $p=0.811$ & $p=0.490$ \\
\hline \multirow[t]{2}{*}{ Longitudinal diameter of stone } & $\mathrm{R}=0.528^{* *}$ & $\mathrm{R}=0.407^{* *}$ & $\mathrm{R}=0.188$ & $\mathrm{R}=0.409^{* *}$ \\
\hline & $\mathrm{p}<0.001$ & $\mathrm{p}<0.001$ & $p=0.115$ & $\mathrm{p}<0.001$ \\
\hline \multirow[t]{2}{*}{ Transvers diameter of stone } & $\mathrm{R}=0.317^{* *}$ & $\mathrm{R}=0.179$ & $\mathrm{R}=0.001$ & $\mathrm{R}=0.265^{*}$ \\
\hline & $p=0.007$ & $p=0.133$ & $p=0.993$ & $p=0.024$ \\
\hline \multirow[t]{2}{*}{ Stone volume } & $\mathrm{R}=0.305^{* *}$ & $\mathrm{R}=0.231$ & $R=0.042$ & $\mathrm{R}=0.215$ \\
\hline & $p=0.009$ & $p=0.050$ & $p=0.724$ & $p=0.070$ \\
\hline \multirow[t]{2}{*}{ HUmax } & $\mathrm{R}=0.323^{* *}$ & $R=0.193$ & $R=0.135$ & $\mathrm{R}=0.207$ \\
\hline & $p=0.006$ & $p=0.104$ & $p=0.258$ & $p=0.081$ \\
\hline \multirow[t]{2}{*}{ HUmin } & $\mathrm{R}=0.278^{*}$ & $R=0.090$ & $R=0.057$ & $\mathrm{R}=0.173$ \\
\hline & $p=0.018$ & $p=0.451$ & $p=0.633$ & $p=0.147$ \\
\hline \multirow[t]{2}{*}{ HUave } & $\mathrm{R}=0.322^{* *}$ & $R=0.154$ & $\mathrm{R}=0.104$ & $\mathrm{R}=0.203$ \\
\hline & $p=0.006$ & $p=0.197$ & $p=0.383$ & $p=0.087$ \\
\hline \multirow[t]{2}{*}{ HUdiff } & $\mathrm{R}=0.101$ & $R=0.164$ & $R=0.122$ & $\mathrm{R}=0.072$ \\
\hline & $p=0.397$ & $p=0.169$ & $p=0.307$ & $p=0.547$ \\
\hline \multirow[t]{2}{*}{$\mathrm{HD}$} & $\mathrm{R}=-0.300^{* *}$ & $\mathrm{R}=-0.242^{*}$ & $R=-0.074$ & $\mathrm{R}=-0.312^{* *}$ \\
\hline & $p=0.010$ & $p=0.040$ & $p=0.537$ & $p=0.008$ \\
\hline
\end{tabular}

${ }^{* *}$ Correlation is significant at the 0.01 level, ${ }^{*}$ Correlation is significant at the 0.05 level

BMI: Body mass index, HUmax: Highest Hounsfield units value, HUmin: Lowest hounsfield units value, HUave: Average of hounsfield units values, HUdiff: Difference of hounsfield units values, HD: Hounsfield density, URS: Ureterorenoscopy

\section{Discussion}

NCCT images provide more information about stone characteristics and stone density including HU measurements. $\mathrm{HU}$ measurements have been researched many times to date and an absolute inverse correlation has been found between high HU level and SF rates after SWL, URSL and PNL procedures. $(9,10,11,12)$. Especially for URSL, stone fragmentation during the procedure is the most important factor for laser energy level, laser time and operative time. Therefore, defining the predictive factors affecting stone fragmentation is one of the major areas of research for URSL in recent years. In a recent study designed by Ito et al. (10), 219 patients who underwent URSL procedures for renal stones were retrospectively analyzed. There was a significant difference in the fragmentation efficiency and operative time in favor of the low HUave group $(<1061$ $\mathrm{HU})$ compared to the high HUave group ( $\geq 1061 \mathrm{HU})$ in URSL procedures for $<20.0 \mathrm{~mm}$ renal stones (10). However, we agreed with Ofude et al. (13) and we also evaluated both total laser time and URS time because laser time is more predictive than operative time. Ofude et al. (13) found that stone attenuations such as HUave and stone volume predicted laser energy level during URSL with Ho:YAG laser. Also, maximum stone diameter and severe hydronephrosis rate were found to be associated with laser energy amount. However, other radiological findings were not found to predict the laser energy levels, such as $H D$, whereas HD was found to be inversely correlated with stone volume. Therefore, the authors considered that HD was insufficient as an indicator of stone density. Also, Seitz et al. (17) retrospectively analyzed 543 patients with ureteral stones who underwent URS. The degree of hydronephrosis was found to be positively correlated with stone size (17). In contrast, stone diameter, volume and HU measurements were not found to be significantly different between the groups with presence of obstruction and presence of impaction in our study.

In an important study published by Molina et al. (18), stone volume, presence of renal stone and HD were found to be significantly positively correlated with laser energy level and stone volume and HD were significantly positively correlated with laser time. Also, size of laser probe and laser power setting were found to be positively correlated with laser energy level. In addition, another study reported that increasing laser settings that may increase laser energy level is associated with high intraluminal temperature, potentially causing ureteral tissue injury (19). When we look at our study; first, laser time was strongly correlated with stone diameter, stone volume, HUmax, HUmin and HUave measurements and negatively correlated 
Table 3. Patients and stone characteristics in laser probe groups and comparison of preoperative predictors and peroperative laser data between the groups in distal ureteral stones by Mann-Whitney $U$ and Pearson chi-square tests

\begin{tabular}{|c|c|c|c|c|}
\hline & & $\begin{array}{l}\text { Laser probe } 365 \mu \mathrm{m} \\
(n=17)\end{array}$ & $\begin{array}{l}\text { Laser probe } 550 \mu \mathrm{m} \\
(\mathrm{n}=55)\end{array}$ & $\mathbf{p}$ \\
\hline Mean Age (year) & & $45.8 \pm 13.7$ & $47.2 \pm 13.1$ & 0.591 \\
\hline BMI (kg/m2) & & $25.1 \pm 3.2$ & $26 \pm 3$ & 0.353 \\
\hline Longitudinal diameter of stone (mm) & & $10.3 \pm 3$ & $10.7 \pm 3.9$ & 0.968 \\
\hline Transvers diameter of stone $(\mathrm{mm})$ & & $9 \pm 4.3$ & $8 \pm 2.7$ & 0.619 \\
\hline Stone volume $\left(\mathrm{mm}^{3}\right)$ & & $470 \pm 890.8$ & $399.4 \pm 450.9$ & 0.868 \\
\hline HUmax (HU) & & $1113.9 \pm 252.9$ & $1117.7 \pm 291.7$ & 0.921 \\
\hline $\mathrm{HU} \min (\mathrm{HU})$ & & $794.4 \pm 274.1$ & $776.2 \pm 254.7$ & 0.842 \\
\hline HUave (HU) & & $954.1 \pm 248.4$ & $947 \pm 255.8$ & 0.974 \\
\hline HUdiff (HU) & & $319.5 \pm 177$ & $341.5 \pm 195.5$ & 0.822 \\
\hline $\mathrm{HD}(\mathrm{HU} / \mathrm{mm})$ & & $111.5 \pm 33.8$ & $111.9 \pm 40.6$ & 0.942 \\
\hline Laser time (min) & & $6.4 \pm 4.9$ & $10.5 \pm 6.1$ & 0.007 \\
\hline Laser energy (joule) & & $580.8 \pm 1028.1$ & $2975.2 \pm 3095.6$ & $<0.001$ \\
\hline Laser energy/time ratio (J/min) & & $85.8 \pm 85.6$ & $259.5 \pm 181.4$ & $<0.001$ \\
\hline URS time (min) & & $20.6 \pm 10.3$ & $24.5 \pm 10.6$ & 0.149 \\
\hline \multirow[t]{2}{*}{ Single session URSL success, $\mathrm{n}$} & Yes & 16 & 52 & \multirow[t]{2}{*}{0.946} \\
\hline & No & 1 & 3 & \\
\hline \multirow[t]{3}{*}{ Usage of forceps and/or basket catheter } & Forceps & 12 & 39 & \multirow[t]{3}{*}{0.888} \\
\hline & Basket & 4 & 11 & \\
\hline & Forceps and basket & 1 & 5 & \\
\hline \multirow[t]{2}{*}{ J stent status, $n$} & Yes & 12 & 37 & \multirow[t]{2}{*}{0.798} \\
\hline & No & 5 & 18 & \\
\hline \multirow[t]{2}{*}{ Previous SWL status, $\mathrm{n}$} & Yes & 6 & 5 & \multirow[t]{2}{*}{0.009} \\
\hline & No & 11 & 50 & \\
\hline \multirow[t]{3}{*}{ Obstruction presence, $\mathrm{n}$} & No & 12 & 25 & \multirow[t]{3}{*}{0.091} \\
\hline & Partial & 2 & 22 & \\
\hline & Complete & 3 & 8 & \\
\hline \multirow[t]{3}{*}{ Impacted stone presence, $\mathrm{n}$} & No & 12 & 28 & \multirow[t]{3}{*}{0.192} \\
\hline & Partial & 2 & 19 & \\
\hline & Complete & 3 & 8 & \\
\hline
\end{tabular}

BMI: Body mass index, HU: Hounsfield units, HUmax: Highest hounsfield units value, HUmin: Lowest hounsfield units value, HUave: Average of hounsfield units values, HUdiff: Difference of hounsfield units values, HD: Hounsfield density, SWL: Extracorporeal shock wave lithotripsy. URS: Ureterorenoscopy, URLS: Ureteroscopic lithotripsy

with HD. Second, URS time was found to be positively correlated with stone diameter and negatively correlated with HD. Last, laser energy level was also positively correlated with only longitudinal stone diameter and negatively correlated with HD. In contrast, the energy/time ratio was not found to correlate with any predictive data.

When we look at previous literature on the type of laser probe, Vassar et al. (20) reported that higher energy level was generated by smaller laser fibers than by larger fibers. In our study, in the analysis of laser probe groups, laser time, laser energy level and laser energy/time ratio were found to be significantly lower in the $365 \mu \mathrm{m}$ group compared to the $550 \mu \mathrm{m}$ group $(\mathrm{p}<0.05)$. In addition, the $365 \mu \mathrm{m}$ probe shortened URS time compared to the $550 \mu \mathrm{m}$ probe, although not statistically significant. Interestingly, the rate of previous SWL was found to be higher in the $365 \mu \mathrm{m}$ probe group. Although SWL may affect stones, stone characteristics were found to be similar between the groups in the study. Therefore, all parameters were evaluated after the exclusion of patients with previous SWL. Similar results were achieved and also URS time was statistically shorter in the 365 $\mu \mathrm{m}$ group. 


\section{Study Limitations}

There are several limitations in this study. The most important limitation is the small number of patients in the study because of the different laser setting selection by different surgeons. Therefore, many patients who underwent URSL with different laser settings for distal ureteral stone were not included in the study. Other limitation is that previous SWL status was different between the groups. However, similar results were achieved after the exclusion of patients with previous SWL. Another limitation is that the distribution of patients according to laser probe selection was not similar between the groups because of the limited number of times the $365 \mu \mathrm{m}$ probe was used during the study. Nonetheless, the results of this study showed that stone diameter, stone volume and HU parameters measured by NCCT are predictors of laser energy level and laser time. Also, the $365 \mu \mathrm{m}$ laser probe decreases the laser energy level, laser time and laser energy/time ratio compared to the $550 \mu \mathrm{m}$ probe.

\section{Conclusion}

In conclusion, for URSL procedures, it is important to acknowledge that NCCT measurements of the stone are effective predictive factors for operative time and laser energy level. Thinner probe usage decreases total laser time, laser energy level and laser energy/time ratio. In addition, thinner laser probe shortens URS time. Nevertheless, for clarification of these results further randomised, prospective studies with large series are warranted.

\section{Ethics}

Ethics Committee Approval: Dokuz Eylul University Ethics Committee, ethical protocol number: 1966 GOA, 2015/06-16.

Informed Consent: It was taken.

Peer-review: Externally peer-reviewed.

\section{Authorship Contributions}

Concept: S.Ç, O.B, I.B., Ö.G., Design: S.Ç, O.B, I.B., Ö.G., Data Collection and/or Processing: S.C, O.B, I.B., 0.G., Analysis and/or Interpretation: Ö.D., M.S., A.E., Literature Research: S.Ç, O.B, I.B., Ö.G., Writing: S.Ç., O.B.

Conflict of Interest: No conflict of interest was declared by the authors.

Financial Disclosure: The author declared that this study has received no financial support.

\section{References}

1. Assimos D, Krambeck $A$, Miller NL, Monga M, Murad MH, Nelson CP, Pace KT, Pais VM Jr, Pearle MS, Preminger GM, Razvi H, Shah O, Matlaga BR. Surgical Management of Stones: American Urological Association/ Endourological Society Guideline. J Urol 2016;196:1153-60.
2. Marks AJ, Teichman JM. Lasers in clinical urology: state of the art and new horizons. World J Urol 2007;25:227-233.

3. Alexander $\mathrm{B}$, Fishman $\mathrm{Al}$, Grasso M. Ureteroscopy and laser lithotripsy: technologic advancement. World J Urol 2015;33:247-256.

4. Francesca F, Scattoni V, Nava L, Pompa P, Grasso M, Rigatti P. Failures and complications of transurethral ureteroscopy in 297 cases: conventional rigid instruments vs. small caliber semirigid ureteroscopes. Eur Urol 1995;28:112115.

5. Yaycioglu O, Guvel S, Kilinc F, Egilmez T, Ozkardes H. Results with 7.5F versus $10 \mathrm{~F}$ rigid ureteroscopes in treatment of ureteral calculi. Urology 2004;64:643-646.

6. Perez Castro $E$, Osther PJ, Jinga V, Razvi $H$, Stravodimos KG, Parikh K Kural AR, de la Rosette JJ; CROES Ureteroscopy Global Study Group. Differences in ureteroscopic stone treatment and outcomes for distal, mid-, proximal, or multiple ureteral locations: the Clinical Research Office of the Endourological Society ureteroscopy global study. Eur Urol 2014;66:102109.

7. Fielding JR, Steele G, Fox LA, Heller H, Loughlin KR. Spiral computerized tomography in the evaluation of acute flank pain: a replacement for excretory urography. J Urol 1997;157:2071-2073.

8. Williams JC, Kim SC, Zarse CA, McAteer JA, Lingeman JE. Progress in the use of helical CT for imaging urinary stones. J Endourol 2004;18:937-941.

9. El-Assmy A, Abou-el-Ghar ME, el-Nahas AR, Refaie HF, Sheir KZ. Multidetector computed tomography: role in determination of urinary stones composition and disintegration with extracorporeal shock wave lithotripsy-an in vitro study. Urology 2011;77:286-290.

10. Ito $H$, Kawahara $T$, Terao $H$, Ogawa $T$, Yao $M$, Kubota $Y$, Matsuzaki J. Predictive value of attenuation coefficients measured as hounsfield units on noncontrast computed tomography during flexible ureteroscopy with holmium laser lithotripsy: A single-center experience. J Endourol 2012;26:1125-1130.

11. Gücük A, Uyetürk U, Oztürk U, Kemahli E, Yildiz M, Metin A. Does the hounsfield unit value determined by computed tomography predict the outcome of percutaneous nephrolithotomy? J Endourol 2012;26:792-796.

12. Celik S, Bozkurt O, Kaya FG, Egriboyun S, Demir O, Secil M, Celebi I. Evaluation of computed tomography findings for success prediction after extracorporeal shock wave lithotripsy for urinary tract stone disease. Int Urol Nephrol 2015;47:69-73.

13. Ofude M, Shima $T$, Yotsuyanagi $S$, Ikeda D. Stone Attenuation Values Measured by Average Hounsfield Units and Stone Volume as Predictors of Total Laser Energy Required During Ureteroscopic Lithotripsy Using Holmium:Yttrium-Aluminum-Garnet Lasers. Urology 2017;102:48-53.

14. Celik S, Altay C, Bozkurt O, Kaya FG, Demir O, Secil M. The Role of Computed Tomography Findings in Prediction of Stone Composition. J Urol Surg 2017:4:91-93.

15. Celik S, Sefik E, Basmacı I, Bozkurt IH, Aydın ME, Yonguc T, Degirmenci T. A novel method for prediction of stone composition: the average and difference of Hounsfield units and their cut-off values. Int Urol Nephrol 2018;50:1397-1405.

16. Nakada SY, Hoff DG, Attai S, Heisey D, Blankenbaker D, Pozniak M. Determination of stone composition by noncontrast spiral computed tomography in the clinical setting. Urology 2000;55:816-819.

17. Seitz C, Tanovic E, Kikic C, Fajkovic H. Impact of stone size, location, composition, impaction, and hydronephrosis on the efficacy of holmium:YAG-laser ureterolithotripsy. Eur Urol 2007;52:1751-1757.

18. Molina WR, Marchini GS, Pompeo A, Sehrt D, Kim FJ, Monga M. Determinants of holmium:yttrium-aluminum-garnet laser time and energy during ureteroscopic laser lithotripsy. Urology 2014;83:738-744.

19. Wollin DA, Carlos EC, Tom WR, Simmons WN, Preminger GM, Lipkin ME. Effect of Laser Settings and Irrigation Rates on Ureteral Temperature During Holmium Laser Lithotripsy, an In Vitro Model. J Endourol 2018;32:59-63.

20. Vassar GJ, Teichman JM, Glickman RD. Holmium: YAG lithotripsy efficiency varies with energy density. J Urol 1998;160:471-476. 